\title{
INVESTIGATIONS OF VARIOUS CW TERAHERTZ PHOTOMIXERS
}

\author{
A. Urbanowicz ${ }^{\text {a }}$, A. Geižutis ${ }^{\mathrm{a}, \mathrm{b}}$, and A. Krotkus ${ }^{\mathrm{a}}$ \\ ${ }^{\text {a }}$ Semiconductor Physics Institute, A. Goštauto 11, LT-01108 Vilnius, Lithuania \\ E-mail: aurban@pfi.lt \\ ${ }^{\mathrm{b}}$ Department of Electronic Systems, Vilnius Gediminas Technical University, Naugarduko 41, LT-03227 Vilnius, Lithuania
}

Received 29 January 2009; revised 3 August 2009; accepted 15 September 2009

\begin{abstract}
Various cw terahertz (THz) photomixers were investigated and compared. Beams of two cw, tunable, single mode DFB (distributed feedback) diode lasers were used for illumination of the devices. Simple photoexcited gap structure, spiral-type and dipole-type integrated antennae patterns photomixers were used while carrying out investigations. $\mathrm{Cw} \mathrm{THz}$ radiation has been generated by photoconductive devices made using low-temperature-grown GaAs layers. Antennae fabricated on GaAs and $\mathrm{GaBiAs}$ layers were used for coherent detection of $\mathrm{cw} \mathrm{THz}$ radiation. It was obtained that the sensitivity of GaBiAs detectors is more than two times higher than in the case of GaAs detectors. GaAs emitters with integrated spiral-type antennae were most efficiently emitting in the low frequency range; enhanced bias voltages of such devices result in generated $\mathrm{THz}$ power comparable with the photomixers with interdigitated contact structures.
\end{abstract}

Keywords: optical mixing, terahertz radiation, GaAs, GaBiAs

PACS: $42.65 . \operatorname{Re}, 72.30 .+\mathrm{q}, 78.47 .+\mathrm{p}$

\section{Introduction}

High resolution spectroscopic measurements in the terahertz $(\mathrm{THz})$ frequency range are becoming increasingly important in various research fields, and tunable coherent radiation sources are essential to the development of systems suited for such spectroscopic measurements. Spectral resolution of optoelectronic timedomain spectroscopy systems employing femtosecond laser pulses and ultrafast photoconductor components [1] is insufficient for characterization of gaseous and molecular media. Optical heterodyne down-conversion (photomixing) in ultrafast photodetectors is one of the most promising sources for high-resolution $\mathrm{THz}$ spectroscopy systems. Narrow-band radiation at the optical beat frequency was observed from photodetectors illuminated by two optically delayed parts of linearly chirped laser pulses [2,3], by a single laser emitting simultaneously at two wavelengths [4], or by heterodyne mixing of two individual cw lasers in a photoconductor $[5,6]$. Low-temperature-grown GaAs photomixers pumped by two $\mathrm{cw}$, tunable, frequency-offset solid-state lasers have been used to generate coherent $\mathrm{cw}$ far-infrared radiation tunable to $3.8 \mathrm{THz}$ with high conversion efficiency [5].

Photomixers usually contain interdigitated electrode structures with few micron wide contact separation that experience a voltage or temperature induced breakdown and are rather fragile. Devices containing a simple photosensitive gap without interdigitated metallization stripes, which are typically used in pulsed $\mathrm{THz}$ radiation components, are more stable but considerably less efficient for $\mathrm{THz}$ generation. To our knowledge structures without interdigitated electrodes excited by two diode lasers were used for coherent $\mathrm{THz}$ generation and detection only once, by Wilk et al. [7]. In the present work, we had compared the results obtained on photomixers with simple photoexcited gap structure and two different integrated antennae patterns. It has been demonstrated that enhanced bias voltages of such devices result in generated $\mathrm{THz}$ power comparable to that of photomixers with interdigitated contact structures.

\section{Experimental details}

Experimental set-up is shown schematically in Fig. 1. Two single-mode laser diodes (Toptica DL 100) emitting $\mathrm{cw}$ in the vicinity of $850 \mathrm{~nm}$ were used. The wavelength of one of the laser diodes was set to $\sim 850 \mathrm{~nm}$, whereas the second laser wavelength was tuned by temperature control in the range from 850 to $855 \mathrm{~nm}$. Because 1-nm difference in the emission wavelengths of both lasers corresponded to a frequency difference of approximately $0.4 \mathrm{THz}$, this has allowed us to tune the 


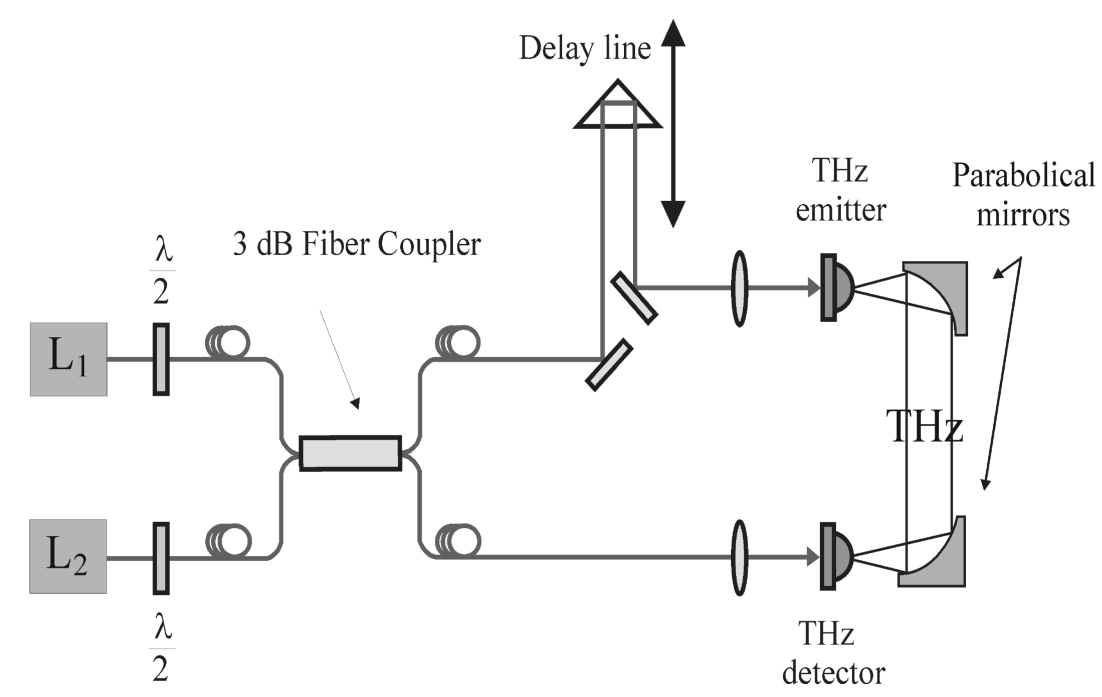

Fig. 1. Photomixing set-up.

optical beating frequency in the range from $100 \mathrm{GHz}$ to $2 \mathrm{THz}$. Both laser beams were combined in a fibreoptical $3 \mathrm{~dB}$ splitter; one of the output beams was used for the photoconductive emitter excitation, and another, passing through a variable length optical delay line, for the photoconductive $\mathrm{THz}$ detector excitation. Optical polarization of the beams was changed for the best interference by two $\lambda / 2$ plates. Intensities of the beams exciting both photoconductive components were of the order of $20 \mathrm{~mW}$.

Ultrafast photoconductors were fabricated from Bedoped low-temperature-grown GaAs (LTG GaAs) epitaxial layers [8] with photolitographically processed microstrip antennae structures on the top. LTG GaAs layers were grown by molecular-beam-epitaxy (MBE) at the substrate temperature of $280^{\circ} \mathrm{C}$ and $\mathrm{As} / \mathrm{Ga}$ beamequivalent pressure rate equal to 10 . The layers were doped during the growth with beryllium at a nominal doping level of $2 \cdot 10^{17} \mathrm{~cm}^{-3}$ and post-growth annealed in a rapid-thermal-annealing oven for $30 \mathrm{~s}$ at $600^{\circ} \mathrm{C}$. Two types of the emitter antennae were investigated (Fig. 2). First of the antennae was of a Hertzian dipole type with two parallel $20 \mu \mathrm{m}$ wide and $5 \mathrm{~mm}$ long gold stripes separated by a $50 \mu \mathrm{m}$ gap. In the central part of

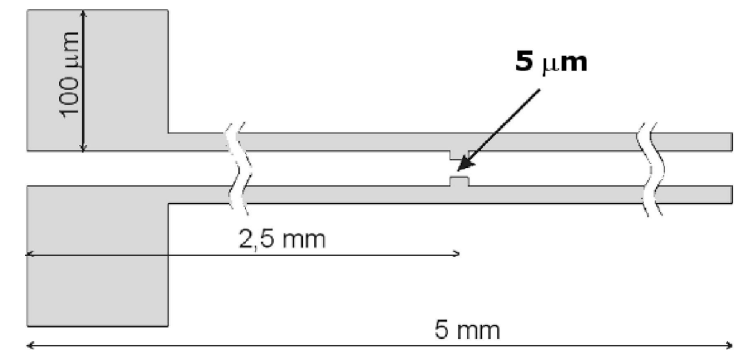

(a) the stripes a $5 \mu \mathrm{m}$ wide photoexcited gap was formed. Another antenna consisted of two spirals with a gap in the central part equal to $40 \mu \mathrm{m}$. THz detectors had dipole type antennae; besides the detectors made from LTG GaAs, a device made from LTG GaBiAs was also investigated for comparison. $\mathrm{THz}$ emitters and detectors were equipped with hemispherical substrate lenses made from high-resistivity silicon crystal.

For coherent $\mathrm{THz}$ generation and detection, the photoconductive emitter was biased by meander-shaped pulses with the repetition rate of $30 \mathrm{kHz}$ and amplitudes up to $30 \mathrm{~V}$. THz beam was propagating without any additional optics towards the detector. The electrical signal from the detector was measured by a lock-in amplifier synchronized to the bias pulses frequency. Delay line was used to change the phase between the optical beat and the $\mathrm{THz}$ beam, at the detector.

The detected signal varies with the time delay, $t^{\prime}$, between the $\mathrm{THz}$ and infrared beams according to the autocorrelation function:

$$
V_{\text {out }} \propto \int_{-\infty}^{\infty} \cos (\omega t) \cos \left[\omega\left(t+t^{\prime}\right)+\phi\right] \mathrm{d} t,
$$

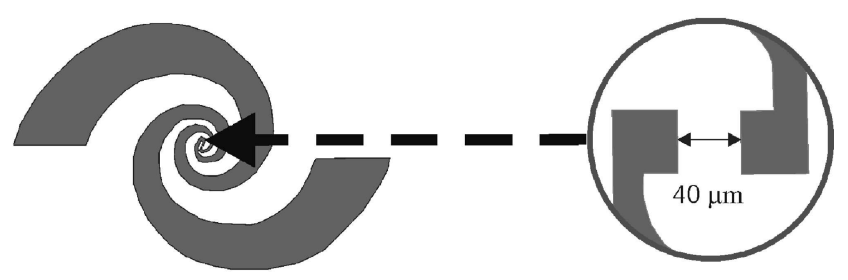

(b)

Fig. 2. Schematic diagram of the emitter antenna: (a) Hertzian dipole type antenna and (b) spiral type antenna. 

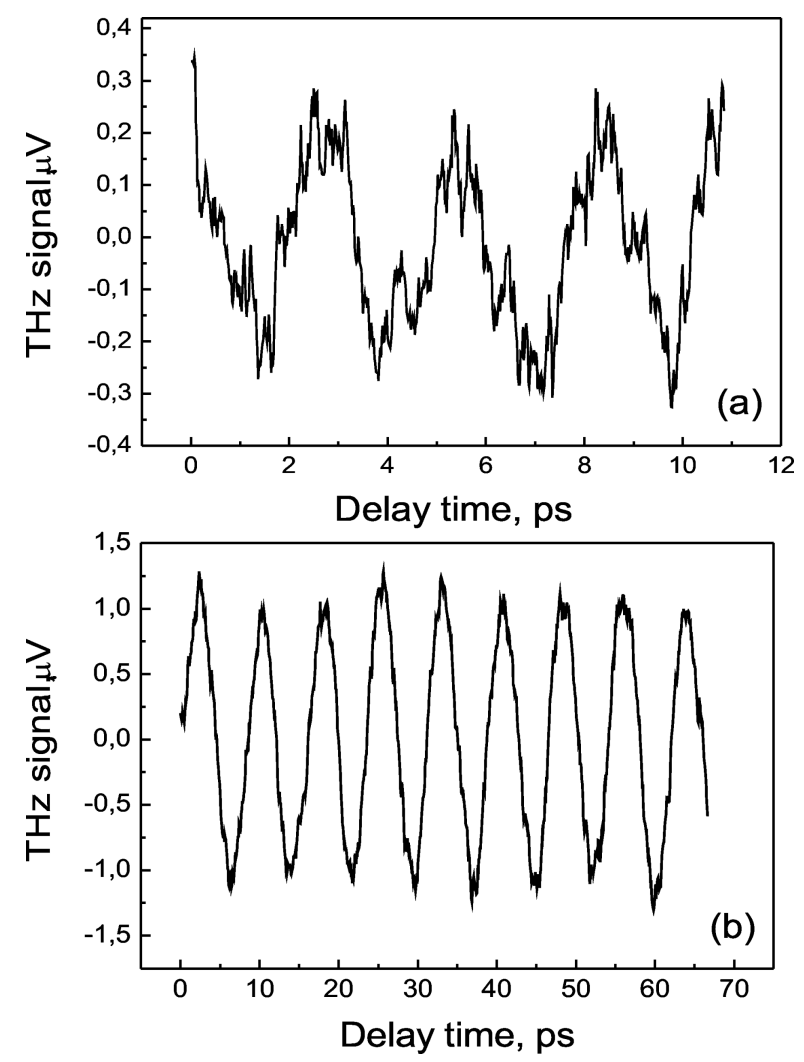

Fig. 3. Measured THz signal amplitudes as a function of the time delay of optical pulses exciting the THz detector made from LTG GaAs. These signals were radiated by (a) a dipole antenna and (b) a spiral antenna, both manufactured from LTG GaAs layer.

here $\phi$ is phase between the incoming $\mathrm{THz}$ beam and the beat in the optical field. Therefore, averaged over $\mathrm{THz}$ time scales, the delay line maps out a sinusoidal variation at the $\mathrm{THz}$ frequency, and both amplitude and phase can be recovered.

In another experiment, the output power of $\mathrm{THz}$ emitters was directly measured by the calibrated Golay cell (Tydex).

\section{Results and discussion}

Figure 3 shows the dependences of the detected $\mathrm{THz}$ signal amplitudes on the time delay of optical pulses exciting the $\mathrm{THz}$ detector made from LTG GaAs. These signals were emitted by a dipole antenna (Fig. 3(a)) and a spiral antenna (Fig. 3(b)). Both photomixers were manufactured using LTG GaAs layer and biased at the same $30 \mathrm{~V}$ voltage. Optical power incident onto the emitter depends on time according to

$$
P(t)=P_{1}+P_{2}+2 \sqrt{m P_{1} P_{2}} \cos \left[\left(\omega_{1}-\omega_{2}\right) t+\varphi\right],
$$

where $P_{1}$ and $P_{2}$ are the powers of two separate optical beams, $\omega_{1}$ and $\omega_{2}$ are beam frequencies, $\varphi$ is the phase

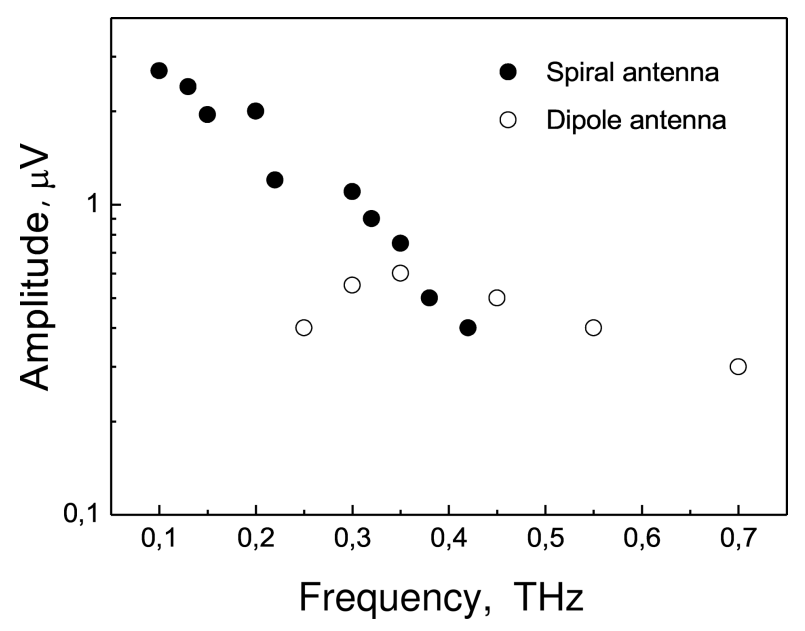

Fig. 4. Amplitudes of THz signals generated by two different emitter structures measured at different oscillation frequencies.

difference between the optical fields in both beams, and $m$ is the photomixing efficiency. THz power radiated by different emitters primarily depends on the parameters of the semiconductor material from which they are manufactured: optical absorption length, lifetimes of photoexcited electrons and holes, and, most importantly, their mobilities. Moreover, THz emitters made from the same semiconductor material differ in the outcoupling of the radiation into the free space determined by the properties of used antennae.

The amplitudes of THz signals, generated by two different emitter structures and measured at different oscillation frequencies, are compared in Fig. 4. These frequency dependences are very different. Dipole type antenna is most efficiently radiating when the oscillation frequency is close to its resonance frequency located at $f_{\mathrm{r}}=c /\left(2 n_{\mathrm{r}} L\right) \approx 0.4 \mathrm{THz}(c$ is the velocity of light, $n_{\mathrm{r}}$ is the refractive index of GaAs, and $L$ is the dipole length). On the other hand, spiral antenna is most efficient at low frequencies, where the signal emitted by it is several times stronger than that emitted by the dipoletype antenna. However, THz signal amplitude radiated by the emitter with a spiral antenna is decreasing nearly exponentially with increasing frequency.

The sensitivity of coherent $\mathrm{THz}$ signal detection could be improved if the detector were made from a material with higher electron mobility. In this work we have additionally investigated a $\mathrm{THz}$ detector manufactured from $\mathrm{GaBi}_{0.04} \mathrm{As}_{0.96}$ epitaxial layer grown by MBE on a semi-insulating GaAs substrate at the temperature of $320^{\circ} \mathrm{C}$ [9]. Results of coherent detection of the signal, emitted by the same spiral-type emitter using devices made from LTG GaAs and GaBiAs, are compared in Fig. 5. Electron mobility in LTG GaAs is typically lower than $1000 \mathrm{~cm}^{2} /(\mathrm{V} \mathrm{s})$, whereas 


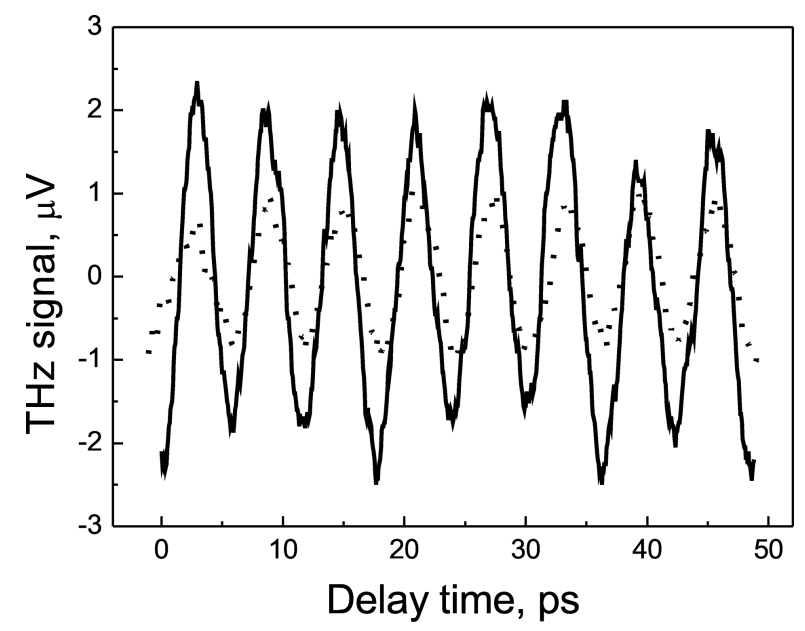

Fig. 5. THz signal generated by the same spiral-type emitter using detector devices made from LTG GaAs (dotted line) and GaBiAs (full line).

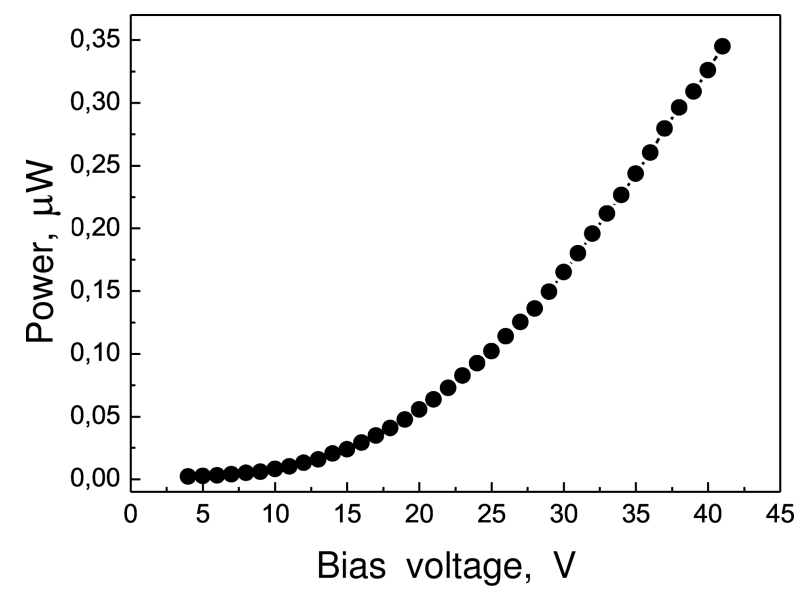

Fig. 6. THz power dependence on the bias voltage of a spiral-type emitter made from LTG GaAs.

LTG GaBiAs, although characterized by subpicosecond electron lifetimes [8] as short as in LTG GaAs, has electron mobilities exceeding $2000 \mathrm{~cm}^{2} /(\mathrm{V} \mathrm{s})[9,10]$. As seen from Fig. 4, in accordance with the ratio of electron mobilities in both materials, signal amplitudes detected using GaBiAs device are larger than those detected when using $\mathrm{THz}$ detector manufactured from LTG GaAs. Therefore, LTG GaBiAs could be a good alternative to LTG GaAs for manufacturing photoconductive photomixers for both $\mathrm{THz}$ radiation generation and detection.

Absolute values of the power radiated by spiral-type emitter were measured by a Golay cell calibrated by the manufacturer using a black-body radiation. Measured $\mathrm{THz}$ power dependence on the emitter bias voltage is shown in Fig. 6. The quadratic bias voltage dependence documented in this figure evidences that the photocurrent amplitude is increasing linearly with the average electric field in the active part of the device even when the electric fields are as high as $10 \mathrm{kV} / \mathrm{cm}$. It means that the electron drift velocity in a LTG GaAs layer, from which the emitter is manufactured, does not saturate at these electric fields, most probably because of high defect density and small low-field mobility in the material. At the largest biases the power of generated $\mathrm{THz}$ signals has been reaching $0.35 \mu \mathrm{W}$, which corresponds to the optical-to-THz conversion efficiency of $\sim 2 \cdot 10^{-5}$, comparable to the best values of this parameter known in the literature $[11,12]$.

\section{Conclusions}

Various cw $\mathrm{THz}$ radiation photomixers, fabricated on low temperature grown GaAs and GaBiAs, were investigated and compared. Two types of antennae, spiral and dipole, were used while carrying out investigations. It was obtained that the sensitivity of GaBiAs detectors was more than two times higher than that in the case of GaAs detectors. GaAs emitters with integrated spiraltype antennae were most efficiently emitting in the low frequency range; in the case of relatively high bias voltages the power of generated $\mathrm{THz}$ signals was reaching $0.35 \mu \mathrm{W}$, which corresponds to the optical-to-THz conversion efficiency of $\sim 2 \cdot 10^{-5}$.

\section{References}

[1] A.C. Warren, N. Katzenellenbogen, D. Grischkowsky, J.M. Woodall, M.R. Melloch, and N. Otsuka, Subpicosecond, freely propagating electromagnetic pulse generation and detection using GaAs:As epilayers, Appl. Phys. Lett. 58, 1512-1514 (1991).

[2] A.S. Weling and D.H. Auston, Novel sources and detectors for coherent tunable narrow-band terahertz radiation in free space, J. Opt. Soc. Am. B 13, 2783-2791 (1996).

[3] M. Hyodo, M. Tani, S. Matsuuro, N. Onodera, and K. Sakai, Generation of millimetre-wave radiation using a dual-longitudinal-mode microchip laser, Electron. Lett. 32, 1589-1591 (1996).

[4] E.R. Brown, K.A. McIntosh, K.B. Nichols, and C.L. Dennis, Photomixing up to $3.8 \mathrm{THz}$ in lowtemperature-grown GaAs, Appl. Phys. Lett. 66, 285287 (1995).

[5] S. Verghese, K.A. McIntosh, S. Calawa, W.F. Dinatale, E.K. Duerr, and K.A. Molvar, Generation and detection of coherent terahertz waves using two photomixers, Appl. Phys. Lett. 73, 3824-3826 (1998).

[6] I.S. Gregory, C. Baker, W.R. Tribe, I.V. Bradley, M.J. Evans, E.H. Linfield, A.G. Davies, and M. Missous, Optimization of photomixers and antennas for 
continuous-wave terahertz emission, IEEE J. Quantum Electron. 41, 717-728 (2005).

[7] R. Wilk, F. Breitfeld, M. Mikulics, and M. Koch, Continuous wave terahertz spectrometer as a noncontact thickness measuring device, Appl. Opt. 14, 3023-3026 (2008).

[8] A. Krotkus, K. Bertulis, M. Kaminska, K. Korona, A. Wolos, J. Siegert, S. Marcinkevicius, J.F. Roux, and J.L. Coutaz, Be-doped low-temperature-grown GaAs material for optoelectronic switches, IEE Proc. Optoelectron. 149(3), 111-115 (2002).

[9] V. Pačebutas, K. Bertulis, L. Dapkus, G. Aleksejenko, A. Krotkus, K.M. Yu, and W. Walukiewicz, Characterization of low-temperature molecular-beam-epitaxy grown GaBiAs layers, Semicond. Sci. Technol. 22, 819-823 (2007).
[10] T. Tiedje, E.C. Young, and A. Mascarenhas, Growth and properties of the dilute bismide semiconductor $\mathrm{GaAs}_{1-x} \mathrm{Bi}_{x}$ a complementary alloy to the dilute nitrides, Int. J. Nanotechnol. 5(9-12), 963-983 (2008).

[11] Anselm J. Deninger, T. Göbel, D. Schönherr, T. Kinder, A. Roggenbuck, M. Köberle, F. Lison, T. Müller-Wirts, and P. Meissner, Precisely tunable continuous-wave terahertz source with interferometric frequency control, Rev. Sci. Instrum. 79, 044702 (2008).

[12] M. Mikulics, M. Marso, I. Cámara Mayorga, R. Güsten, S. Stanček, P. Kováč, S. Wu, X. Li, M. Khafizov, R. Sobolewski, E.A. Michael, R. Schieder, M. Wolter, D. Buca, A. Förster, P. Kordoš, and H. Lüth, Photomixers fabricated on nitrogen-ion-implanted GaAs, Appl. Phys. Lett. 87, 041106 (2005).

\title{
NETRŪKIOS TERAHERCINĖS SPINDULIUOTĖS FOTOMAIŠIKLIŲ TYRIMAI
}

\author{
A. Urbanowicz ${ }^{\text {a }}$, A. Geižutis ${ }^{a, b}$, A. Krotkus ${ }^{\text {a }}$ \\ ${ }^{a}$ Puslaidininkiu fizikos institutas, Vilnius, Lietuva \\ ${ }^{\mathrm{b}}$ Vilniaus Gedimino technikos universitetas, Vilnius, Lietuva
}

\section{Santrauka}

Ištirti ir palyginti skirtingi netrūkios terahercinès $(\mathrm{THz})$ spinduliuotès fotomaišikliai, kurių žadinimui buvo naudojami du derinamo bangos ilgio vienamodžiai lazeriniai diodai. Atliekant tyrimus buvo naudojami dipoliniu ir spiralinių antenų fotomaišikliai. Netrūkios THz spinduliuotès generavimui naudotos dipolinès arba spiralinès antenos, suformuotos ant žemoje temperatūroje (ŽT) au- ginto GaAs sluoksnio paviršiaus. THz spinduliuotė koherentiškai detektuota dipolinemis antenomis, suformuotomis ant ŽT GaAs ir ŽT GaBiAs epitaksinių sluoksnių. Paaiškèjo, kad GaBiAs detektoriu jautris du kartus didesnis nei GaAs detektorių. GaAs emiteriai su spiralinėmis antenomis efektyviausiai generuoja žemų dažnių srityje; didinant maitinimo įtampą šių maišiklių optinès galios vertimo i $\mathrm{THz}$ spinduliuotę efektyvumas siekia $2 \cdot 10^{-5}$. 